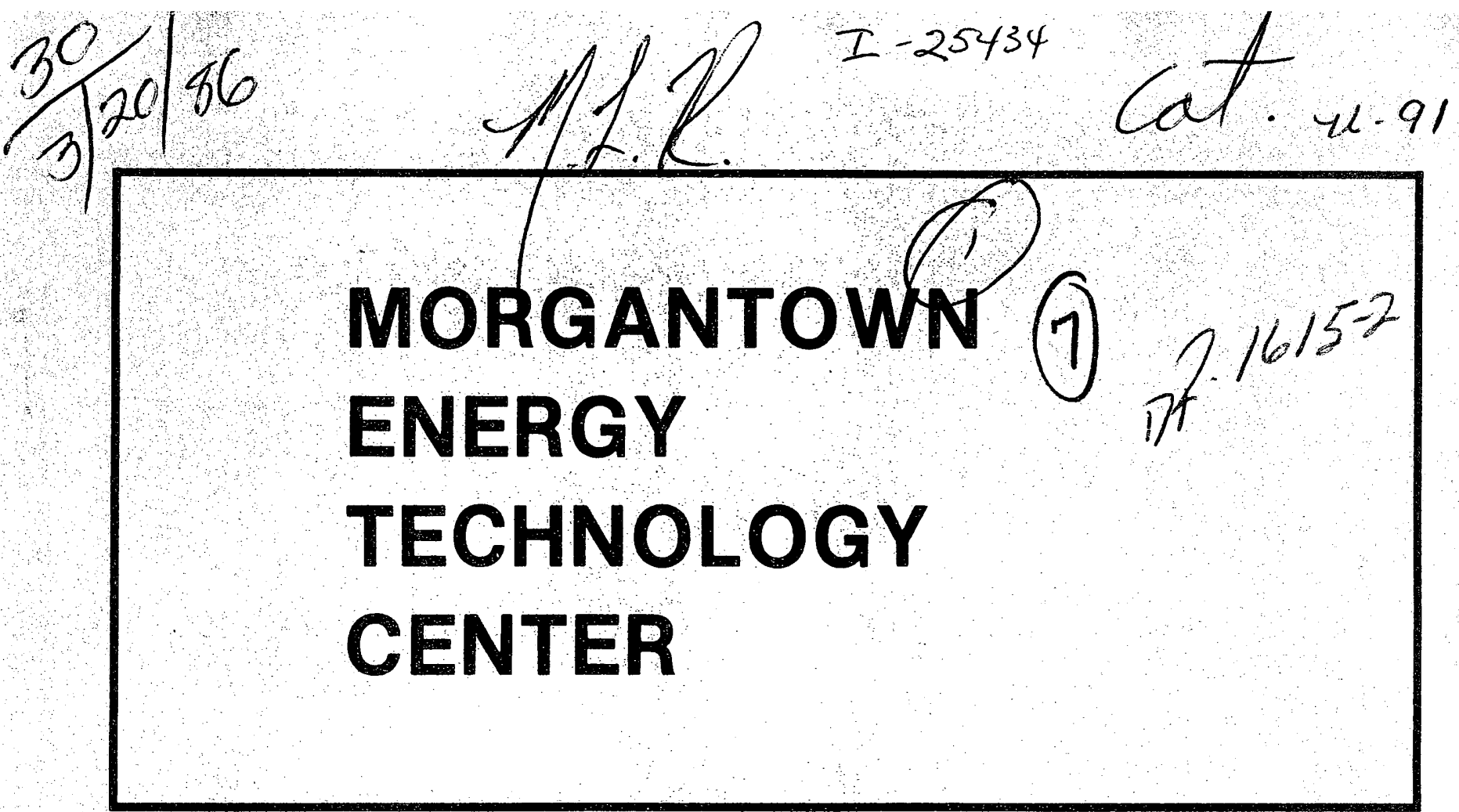

DOE/METC-86/4024

(DE86001066)

Identification of Data Gaps Found During the Development of a Zero-Order Model for a Fluidized-Bed Retort/Combustion Process

Technical Note

By

J.R. Ammer

1.0. WOBOELM

COVER

January 1986

U.S. DEPARTMENT OF ENERGY

OFFICE OF FOSSIL ENERGY

MORGANTOWN ENERGY TECHNOLOGY CENTER

MORGANTOWN, WEST VIRGINIA 


\title{
DISCLAIMER
}

This report was prepared as an account of work sponsored by an agency of the United States Government. Neither the United States Government nor any agency thereof, nor any of their employees, makes any warranty, express or implied, or assumes any legal liability or responsibility for the accuracy, completeness, or usefulness of any information, apparatus, product, or process disclosed, or represents that its use would not infringe privately owned rights. Reference herein to any specific commercial product, process, or service by trade name, trademark, manufacturer, or otherwise does not necessarily constitute or imply its endorsement, recommendation, or favoring by the United States Government or any agency thereof. The views and opinions of authors expressed herein do not necessarily state or reflect those of the United States Government or any agency thereof.
DOE/METC-86/4024

(DE86001066)

DOE/METC- $-86 / 4024$

DE 86001066

\section{Identification of Data Gaps Found During the Development of a Zero-Order Model for a Fluidized-Bed Retort/Combustion Process}

\author{
Technical Note
}

By

J.R. Ammer

U.S. Department of Energy

Office of Fossil Energy

Morgantown Energy Technology Center

P.O. Box 880

Morgantown, West Virginia 26507-0880

January 1986 



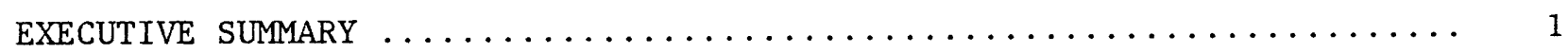

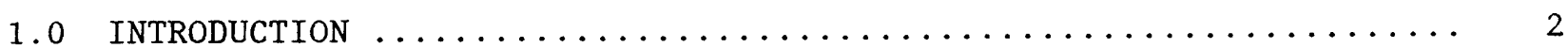

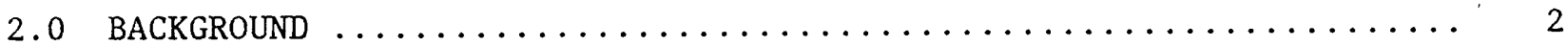

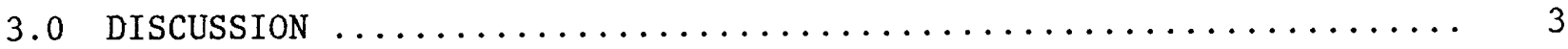

3.1 ASPEN Flow Sheet Description and Assumptions ............ 3

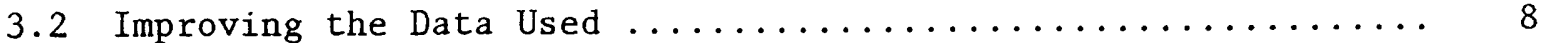

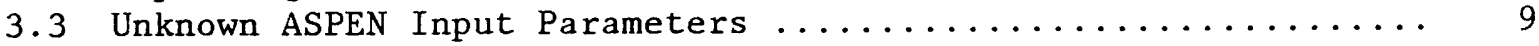

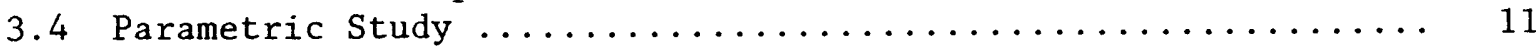

4.0 CONCLUSIONS AND RECOMMENDATIONS $\ldots \ldots \ldots \ldots \ldots \ldots \ldots \ldots \ldots \ldots \ldots \ldots 14$

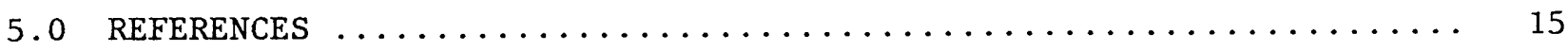

APPENDIX A: ASPEN INPUT FILE FOR THE BASE CASE $\ldots \ldots \ldots \ldots \ldots \ldots \ldots \ldots$

APPENDIX B: CALCULATIONS FOR STOICHIOMETRY OF NEW ALBANY SHALE $\ldots . \ldots .23$

\section{LIST OF FIGURES}

Figure

1 Schematic Diagram of the Fluidized-Bed Oil Shale Retorting

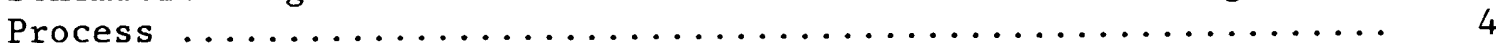

2 Block Diagram of the ASPEN Simulation of an Oil Shale

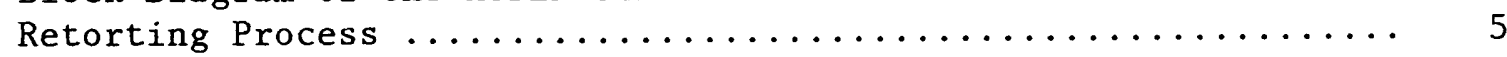

3 Comparison of the Heat Capacity of Muscovite and Illite ....... 13

\section{LIST OF TABLES}

$\underline{\text { Table }}$

1 Mineralogical X-Ray Diffraction Analysis for Kentucky

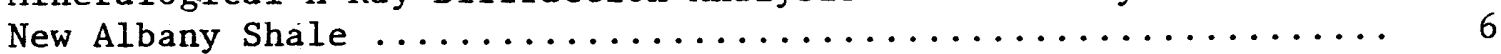

2 Composition of Fluidizing Gas $\ldots \ldots \ldots \ldots \ldots \ldots \ldots \ldots \ldots \ldots \ldots \ldots \ldots \ldots \ldots$

3 Input Parameters/Models for Eastern Oil Shale Retort/ Combustion Process .......................... 10

$4 \quad$ Parametric Study $\ldots \ldots \ldots \ldots \ldots \ldots \ldots \ldots \ldots \ldots \ldots \ldots \ldots \ldots \ldots \ldots$

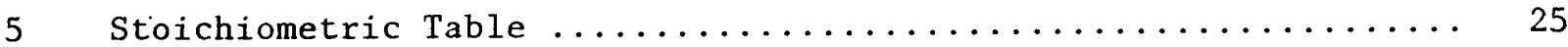


This technical note (TN) reports on the development of a zero-order ASPEN (Advanced System for Process Engineering) model for the fluidized-bed retort/ combustion of an eastern oil shale. The objective of the work described was to identify data needs and to create a structure for future, more definitive models.

New Albany shale was the initial reference eastern shale at the Department of Energy (DOE)/Morgantown Energy Technology Center (METC). A literature search on this shale was conducted to find the physical property data required for the ASPEN model. This TN discusses the types of missing or incomplete data, the process being modeled, and how process variables are affected by varying input parameters. The TN also presents recommendations for increasing the reliability of the simulation. 


\subsection{INTRODUCTION}

DOE/METC has initiated a long-range, in-house systems-analysis research program for oil shale. Systems analysis will be used to identify potential process improvements in the retorting of oil shale that could lead to enhanced operability, improved process economics, or that could mitigate environmental impacts. Systems models are intended eventually to describe the entire shale operation from mining and solids handling to retorting/combustion and spent shale disposal. In this systems analysis program, DOE/METC will simulate a number of oil shale process configurations for both eastern and western shales. The ASPEN code will be the primary simulation tool in this effort.

Fluidized-bed processing of shale offers a flexibility in retorting conditions that far exceeds those available with packed-bed retorting approaches. The advantages of the fluidized-bed process for retorting oil shale are as follows:

- A high in-bed heat transfer rate results in very rapid heating of cold, raw shale particles to retorting temperature.

- A large solids throughput is possible because the good mixing characteristics help create a high degree of bed uniformity and because the raw shale feedstock can attain the desired retorting temperature with a relatively short residence time in the retort.

- Operational flexibility exists because the fluidized-bed can handle a wide variety of oil shale types and particle sizes. For example, the shale fines generated by mining and processing operations tend to block the gas passages of packed-bed retorts but do not hinder fluidized-bed retorts.

- Secondary hydrocarbon cracking in the retort is minimized because of the short residence time of the gaseous retorted hydrocarbon products within the shale matrix.

- Process economics may be improved because the fluidized-bed retort is inherently smaller than packed-bed retorts for a given throughput and offers the potential for modular construction.

\subsection{BACKGROUND}

The Department of Chemical Engineering and Energy Laboratory at the Massachusetts Institute of Technology (MIT) modeled an oil shale fluidized-bed retorting process using the ASPEN process simulator (Fong and others 1981). Their modeling objectives were to determine the thermal balance of the overall process, solids recirculation ratio, effect of carbonate decomposition on heat requirements, and the sensitivity of various operating parameters on the performance of the process. This work was performed for a western oil shale, as a starting point from which to study eastern oil shale. A past study conducted at DOE/METC checked the reproducibility of the MIT model on the METC VAX system and began research on eastern oil shale.

Because eastern and western oil shales differ in many respects, a significant effort was needed to convert the existing MIT fluidized-bed ASPEN model to an oil shale fluidized-bed retort/combustion process model for eastern oil shale. Although the overall process flow sheet and ASPEN unit operation blocks were 
very similar, the numeric values for the physical property input data for eastern shale were quite different from those values given for western shale. Some of the major differences affecting model results are the kerogen composition, which influences the stoichiometric yield of oil, gas, and residue (spent shale), and the composition of minerals and their related physical properties. These data are needed to create a realistic simulation of an eastern oil shale fluidized-bed retort/combustion process.

\subsection{DISCUSSION}

The following sections discuss the ASPEN flow sheet language and assumptions, the input parameters required by ASPEN, methods to improve the data, and a parametric study. Figure 1 shows a schematic diagram of the fluidized-bed oil shale retorting process modeled in this study. The block diagram for the ASPEN simulation flow sheet is shown in Figure 2. The major difference between the actual fluidized-bed process (Figure 1) and the simulation is that the section before the retort, which incorporates the crusher, cyclone, and preheater, is not modeled. In the ASPEN simulation, preheated shale is mixed with the recycled gas and recycled shale prior to entering the retort. The input language for the base case simulation is given in Appendix A.

\subsection{ASPEN FLOW SHEET DESCRIPTION AND ASSUMPTIONS}

- Feed Mixer Block

The feed stream of raw shale, FDSHALE, entered MIX1, an ASPEN mixer block, at $400^{\circ} \mathrm{F}$ where it is combined with the fluidizing gas, FLDZGAS, and the recycled hot shale, RECSHALE. The raw shale was modeled as three substreams: kerogen, minerals, and moisture. Two ultimate analyses of the raw shale, with a few assumptions, was averaged to determine the percent of kerogen, minerals, and moisture (Phillips and others 1984; Battelle 1984). All of the nitrogen, 75 percent of the oxygen, and 15 percent of the sulfur was assumed to be organic; all of the organic components ( $\mathrm{C}, \mathrm{H}, \mathrm{O}, \mathrm{N}$, and $S$ ) was assumed to compose the kerogen. A mineralogical X-ray diffraction analysis was performed by the West Virginia University Geology Department on a sample of New Albany shale to determine the composition of the minerals. (See Table 1.) A FORTRAN block, FEEDRATE, was used to set the flow rate of the three substreams, kerogen, minerals, and moisture, such that the total flow of FDSHALE is $1,000 \mathrm{lb} / \mathrm{hr}$. (A FORTRAN block is a section of FORTRAN statements generally used to set process variables in a once-through calculation.) SET-FLDZGAS, another FORTRAN block, was used to calculate the flow rate of the fluidizing gas, based on the flow rate of the feed stream and recycled shale stream. The composition of the fluidizing gas stream was assumed to be similar in composition to that of the product gas. Table 2 shows the composition of the fluidizing gas.

\section{- Retort}

The new (combined) stream, PRYOLIN, from MIX1 entered the retort block (RETORT1), that was modeled using an ASPEN stoichiometric reactor, or RSTOIC block. Here, a predetermined stoichiometric equation causes all the kerogen to pyrolyze to form oil, gases, and residue. An analysis of the oil product from the retort was obtained from data on a fluidized-bed retort of an eastern oil shale (Jones and others 1984). Using data from 


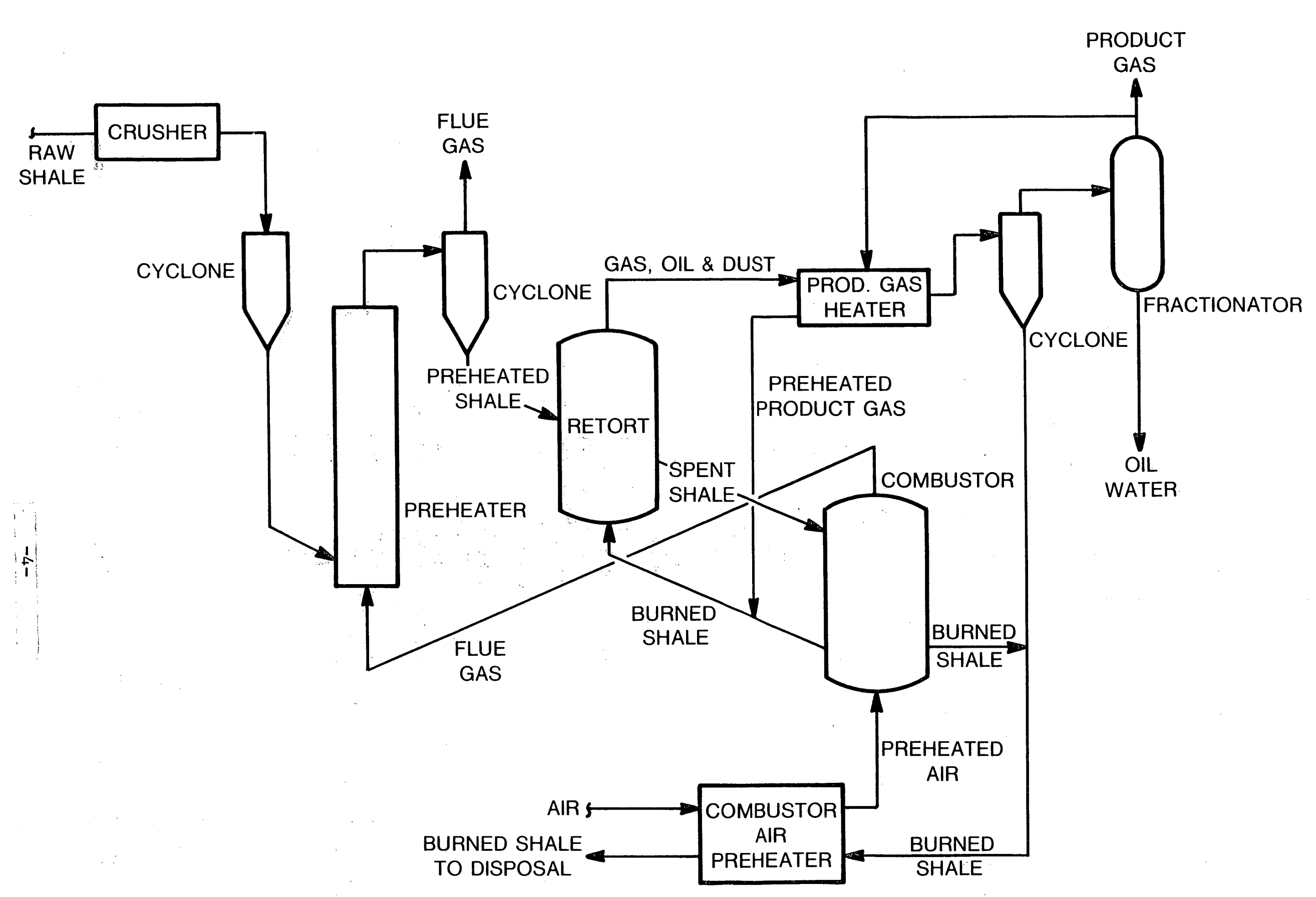

FIGƯRE 1. SCHEMATIC DIAGRAM OF THE FLUIDIZED-BED OIL SHALE RETORTING PROCESS 


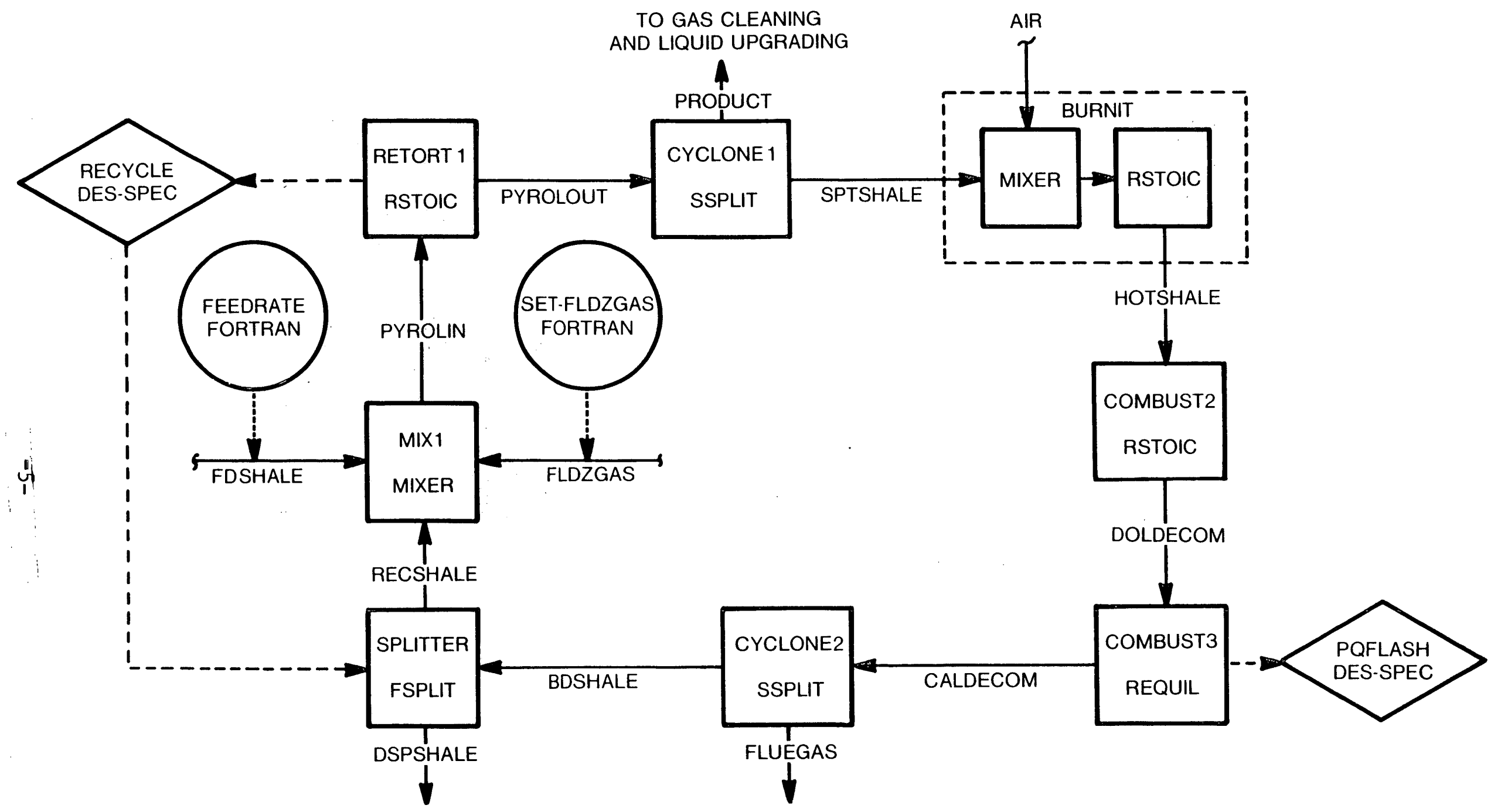

FIGURE 2. BLOCK DIAGRAM OF THE ASPEN SIMULATION OF AN OIL SHALE RETORTING PROCESS 
TABLE 1. MINERALOGICAL X-RAY DIFFRACTION ANALYSIS FOR KENTUCKY NEW ALBANY SHALE

\begin{tabular}{|c|c|}
\hline COMPONENT & WEIGHT \% \\
\hline Illite ${ }^{1}$ & 70.8 \\
\hline Quartz $\left(\mathrm{SiO}_{2}\right)$ & 15.3 \\
\hline Kaolinite $\left(\mathrm{Al}_{2} \mathrm{Si}_{2} \mathrm{O}_{7} \cdot 2 \mathrm{H}_{2} \mathrm{O}\right)$ & 7.2 \\
\hline Pyrite $\left(\mathrm{FeS}_{2}\right)$ & 3.6 \\
\hline Calcium-Sulfate $\left(\mathrm{CaSO}_{4}\right)$ & 1.1 \\
\hline Szomolnokite $\left(\mathrm{FeSO}_{4} \cdot \mathrm{H}_{2} \mathrm{O}\right)$ & 1.0 \\
\hline $\mathrm{K}-\mathrm{Feldspar}\left(\mathrm{KAlSi}_{3} \mathrm{O}_{8}\right)$ & 0.6 \\
\hline Calcite $\left(\mathrm{CaCO}_{3}\right)$ & 0.2 \\
\hline $\begin{array}{l}\text { Dolomite }\left(\mathrm{CaMg}\left(\mathrm{CO}_{3}\right)_{2}\right) / \text { Ankerite } \\
\quad \mathrm{Ca}\left(\mathrm{Mgo}_{.67} \mathrm{Fe}_{0.33}\right)\left(\mathrm{CO}_{3}\right)_{2}\end{array}$ & 0.2 \\
\hline Total & 100.0 \\
\hline
\end{tabular}

${ }^{1}$ Formula not given.

TABLE 2. COMPOSITION OF FLUIDIZING GAS

\begin{tabular}{lr}
\hline COMPONENT & MOLE \% \\
\hline $\mathrm{CH}_{4}$ & 28 \\
$\mathrm{C}_{2} \mathrm{H}_{6}$ & 14 \\
$\mathrm{C}_{3} \mathrm{H}_{8}$ & 10 \\
$\mathrm{C}_{4} \mathrm{H}_{10}$ & 7 \\
$\mathrm{CO}$ & 7 \\
$\mathrm{H}_{2}$ & 34 \\
Total & 100 \\
\hline
\end{tabular}


studies conducted on fluidized-bed retorting of eastern oil shale (Carter and Taulbee 1984; Ahmed, Parker, and Archer 1982), which gave the percent of raw carbon released into the oil and gas (and therefore, the remaining percent of carbon would be left in the residue, the amount of oil that would be formed by pyrolyzing $100 \mathrm{lbs}$ of oil shale was calculated. The gas composition was assumed as were the mole fractions for each component. Then, assuming the pyrolysis of $100 \mathrm{lbs}$. of kerogen, the amount of gas was calculated, for each component and overall. The remaining amount of each element, $\mathrm{C}, \mathrm{H}, \mathrm{O}, \mathrm{N}$, and $S$, was assumed to remain in the residue. Appendix $B$ shows the calculation of the stoichiometric equation and Table 5 is a list of reactants and products formed during the retort. The only reaction involving minerals that was assumed to occur in the retort was the endothermic reaction of pyrite and water. A 35-percent reaction extent of pyrite was obtained from Phillips and others (1984):

$$
\mathrm{FeS}_{2}+2 \mathrm{H}_{2} \mathrm{O} \rightarrow \mathrm{FeO}+2 \mathrm{H}_{2} \mathrm{~S}+\frac{1}{2} \mathrm{O}_{2}
$$

A design specification, RECYCLE, forced the temperature in the retort outlet stream, PYROLOUT, to $950^{\circ} \mathrm{F}$ by varying the percentage of recycled spent shale, RECSHALE. (A design specification varies one process variable in an iterative manner until another variable attains a specified value.) The enthalpy model used to calculate the enthalpy of kerogen was developed by MIT (Fong and others 1981). This model uses Dulong's correlation and the ultimate analysis of kerogen to calculate the heat of combustion and the heat of formation, which are then used to calculate the enthalpy of kerogen.

\section{- Post-Retort Cyclone}

To simplify the simulation, and since data on shale particle size were not available, the cyclone in the process flow sheet was modeled using an ASPEN separator block, SSPLIT. This block separates the vapor phase oil and gases from the spent shale, SPTSHALE. A 100-percent separation of solids is assumed. The gaseous product stream, PRODUCT, is sent for gas cleaning and liquid upgrading; however, these processes were not modeled in this study. The spent shale stream, SPTSHALE, is recycled to the combustor.

\section{- Combustor}

Three ASPEN reactor blocks (BURNIT, COMBUST2, and COMBUST3) and a mixer block were used to model the combustor. BURNIT is an insert, i.e., a file consisting of standard ASPEN input statements that can be called like a FORTRAN subroutine. BURNIT is used to burn a nonconventional component such as spent shale into $\mathrm{CO}_{2}, \mathrm{H}_{2} \mathrm{O}, \mathrm{H}_{2} \mathrm{~S}$, and ash using air as the oxidant. In the simulation, spent shale, SPTSHALE, enters a mixer block where it is combined with air. This stream then enters the first reactor block, BURNIT, where the carbon in the spent shale is combusted. The stoichiometric coefficients for combusting the shale are based on the ultimate analysis of the spent shale. The reaction extent of the carbon combusted and excess amount of oxygen are user-specified. Ninety percent of the carbon was assumed to react, and 10-percent excess oxygen was specified. 
Block COMBUST2 models the endothermic decomposition of dolomite into calcite, magnesium oxide, and carbon dioxide:

$$
\mathrm{CaMg}\left(\mathrm{CO}_{3}\right)_{2} \rightarrow \mathrm{CaCO}_{3}+\mathrm{MgO}+\mathrm{CO}_{2}
$$

The stoichiometric equation and reaction extent are user-specified. The reaction extent is 100 percent. Physical property data for the minerals were obtained from the JANAF Thermochemical Tables (National Bureau of Standards 1971), from data collected by Los Alamos National Laboratory for an ASPEN oil shale properties data base, and from a publication on thermodynamic properties of minerals and related substances (Robie 1978). Data for the mineral muscovite were used for the mineral illite since the two minerals have similar molecular structures.

Block COMBUST3 models the endothermic decomposition of calcite into calcium oxide and carbon dioxide:

$$
\mathrm{CaCO}_{3} \rightarrow \mathrm{CaO}+\mathrm{CO}_{2}
$$

The percentage of calcite that reacts, which is determined by thermodynamic equilibrium, depends upon the temperature of the calcite and the partial pressure of carbon dioxide in the surrounding gas. The decomposition of dolomite and calcite are the only two reactions involving minerals that are assumed to occur in the combustor. A design specification, PQFLASH, forces this block to be adiabatic.

- Post-Combustor Cyclone

CYCLONE2, which models a cyclone using an ASPEN separator block, separates the flue gases, FLUEGAS, from the hot shale stream, BDSHALE. A 100-percent separation of solids is assumed.

- Recycle Splitter

In the block SPLITTER, a percentage of the hot spent shale, BDSHALE, is recycled to MIX1. The remaining shale, DSPSHALE, is disposed of. A design specification, RCYCLE, varies the amount of recycled shale, RECYCLE, until the temperature in the outlet stream from RETORT1 is $950^{\circ} \mathrm{F}$.

\subsection{IMPROVING THE DATA USED}

The simulation could be improved by decreasing the number of assumptions made or improving the data as indicated:

- The organic percentages of oxygen, nitrogen, and sulfur in the raw shale were assumed from the ultimate analysis. The exact amounts of nitrogen and sulfur can be determined by performing an ultimate analysis on the demineralized organic matter of the oil shale. Subtracting carbon, hydrogen, sulphur, and nitrogen from the total raw shale would give the amount of organic oxygen. 
- A mineralogical analysis was conducted on only one sample of New Albany shale. This analysis should be conducted on numerous samples so that the analysis is more representative of the oil shale.

- The three sources used for physical property data of the minerals were in good agreement; however, a problem still remains on what data to use for illite. Both Los Alamos National Laboratory and the Institute for Mining and Minerals Research (IMMR) at the University of Kentucky agree that muscovite is very similar to illite and that using the physical property data of muscovite for illite is reasonable. This assumption should be further investigated.

- The insert BURNIT, which is used to burn a nonconventional component such as spent shale, forms the products $\mathrm{CO}_{2}, \mathrm{H}_{2} \mathrm{O}, \mathrm{H}_{2} \mathrm{~S}$, and ash. This insert would better represent the combustion of a nonconventional component in an oxidizing environment by having $\mathrm{SO}_{2}$ and $\mathrm{NO}_{x}$ as products instead of $\mathrm{H}_{2} \mathrm{~S}$.

- A list of minerals given in the mineralogical analysis of the raw shale, obtained from the West Virginia University Geology Department, was used as an initial set of constituents to describe the shale composition. This analysis was limited to nine major minerals, whose physical properties were found in the literature. As a first approximation, it was felt that this number of components was sufficient for the ASPEN model to generate gross material and energy balances around each of the process units. However, a more complete breakdown of the mineral composition of the shale would lead to future refinements to the simulation.

- The heat of reaction for kerogen decomposition as calculated by the MIT model showed a major discrepancy with values found in the literature (Carley 1975) for western oil shale. Therefore, this model should be checked against experimental data on eastern oil shale to determine its validity. Other ASPEN enthalpy calculation methodologies are available that may be more accurate; however, these were not used in this simulation.

\subsection{UNKNOWN ASPEN INPUT PARAMETERS}

The fluidized-bed retort/combustor process model will provide the framework to build a more rigorous and predictive model as additional information is obtained. However, for this model and future models to be representative of the fluidized-bed process, important input parameters must be well defined. Table 3 shows the list of input parameters for the ASPEN input language given in Appendix A. This section describes the parameters or models with unknown or uncertain values. The known input parameters and their sources, along with assumptions that were made, are discussed in Section 3.1 of this report.

The oil composition and oil physical properties must be better defined. In the MIT study, the product oil from the retort was represented as cyclohexene $\left(\mathrm{C}_{6} \mathrm{H}_{10}\right)$. The heat of formation from the ASPEN data banks was overridden by calculating the heat of formation using Dulong's correlation and the ultimate analysis of the oil. This study represented the product oil from the retort as $\mathrm{n}$-dodecane $\left(\mathrm{C}_{12} \mathrm{H}_{26}\right)$. A better way to represent the oil may be to break down the product oil into cuts (pseudo components) based on the boiling point curve. The physical properties of the cuts can then be determined by using their 
molecular weight, boiling point, and specific gravity. This model for oil shale liquids is currently being developed by Los Alamos National Laboratory.

TABLE 3. INPUT PARAMETERS/MODELS FOR EASTERN OIL SHALE RETORT/COMBUSTION PROCESS

KNOWN
UNKNOWN
Ultimate Analysis of Raw Oil Shale (See Appendix B)

Mineralogic Analysis of Raw Oil Shale (See Table 1)

Physical Properties for Each Mineral in This Simulation

- Heat of Formation

- Gibbs Free Energy of Formation

- Heat Capacity Parameters

- Molar Volume Parameters

Enthalpy Model for Kerogen

Fluidizing Gas Composition

Combustion Model (Insert)
Product Oil Composition

Product Oil Physical Properties

Gas Composition

Ultimate Analysis of Retorted Oil Shale

Ultimate Analysis of Oil Shale After Combustion

Mineralogical Analysis of Oil Shale After Retort

Mineralogical Analysis of 0il Shale After Combustion

Stoichiometry and Extent of Mineral Reactions

Stoichiometry and Extent of Kerogen Pyrolysis

Pyrolysis Model

Hydrodynamic Model

Ultimate analyses and mineralogical analyses should be performed on the oil shale after retorting and after combustion. The stoichiometric equation for the pyrolysis of kerogen was based on many assumptions. (See Appendix B.) The ultimate analyses of the oil shale after retorting and after combustion can be used to strengthen the calculations of the stoichiometric equation by reducing the number of assumptions made. Since little is known of the reactions that take place between the minerals, mineralogical analyses may help determine the stoichiometric equations for these reactions.

All of the above data are determined at specific retorting/combustion conditions. If the oil shale fluidized-bed retort/combustion process model is to be used to 
its fullest extent, the model must be predictive. This gives the modeler the opportunity to do a complete parametric study, varying input data and operating conditions, without making gross assumptions or needing experiments conducted at the set of conditions being modeled.

The best way to model the fluidized-bed retort/combustion process would be to use mechanistic models to predict the thermodynamic and kinetics of reactions and the hydrodynamics of the fluidized-bed system. Lawrence Livermore National Laboratory recently developed a pyrolysis model for the Mahogany Zone Green River oil shale (Burnham and Braun 1984). However, this model is based on experimentation for a range of pyrolysis conditions for the Green River oil shale and is not applicable for an eastern oil shale. It is in this direction that DOE/METC should set its goals, i.e., a predictive model of a fluidized-bed retort/combustion process for eastern shale. Two other models worth mentioning were also developed by Lawrence Livermore: RETORT (Braun 1981) and STBRSIM (Diaz and Braun 1984). RETORT simulates the chemicophysical processes involved in the vertical retorting of a rubblized bed of oil shale. STBRSIM simulates an aboveground oil shale retorting process that utilizes two reactors (a staged, fluidized-bed retort, and a lift-pipe combustor).

\subsection{PARAMETRIC STUDY}

Using the data and assumptions made in the previous sections, a parametric study determined the effects of input parameters on process variables such as combustor temperature and recycle ratio. Parameters included in this study were the heat capacity of illite, the stoichiometric equation, the heat of formation of the product oil from the retort, and the amount of carbon in the residue that was combusted. The retort temperature in these sensitivity studies was fixed at $950^{\circ} \mathrm{F}$. Table 4 shows these parameters and the combustor temperature and recycle ratio for each run and the following text discusses the variations utilized.

TABLE 4. PARAMETRIC STUDY

\begin{tabular}{lccc}
\hline \multicolumn{1}{c}{ PARAMETER VARIED } & $\left.\begin{array}{c}\text { COMBUSTOR } \\
\text { TEMPERATURE }\end{array}{ }^{\circ} \mathrm{F}\right)$ & $\begin{array}{c}\Delta \text { T FROM } \\
\text { BASE CASE }\end{array}$ & $\begin{array}{c}\text { RECYCLE } \\
\text { RATIO }^{1}\end{array}$ \\
\hline Base Case & 2,236 & & .246 \\
Illite Heat Capacity & 2,485 & +249 & .185 \\
$\begin{array}{l}\text { Stoichiometric Equation } \\
\text { (Kerogen Pyrolysis) }\end{array}$ & & & .315 \\
$\begin{array}{l}\text { Percent Carbon Combusted } \\
\text { Heat of Formation of Raw Oil }\end{array}$ & 2,034 & -202 & .286 \\
$\begin{array}{l}\text { All Parameters } \\
\text { (Excluding Illite Heat Capacity) }\end{array}$ & $2,046.190$ & .452 \\
\hline
\end{tabular}

${ }^{1}$ Recycle Ratio $=\frac{\text { mass flow rate of recycled burned shale }}{\text { mass flow rate of raw feed shale }}$ 
Base Case Run -- The base case ASPEN input language is given in Appendix A. A design specification was set around the retort to force the temperature in the outlet stream to $950^{\circ} \mathrm{F}$ by varying the recycle ratio of hot spent shale to raw feed shale. Another design specification around the combustor varied the temperature of the combustor to force the combustor to adiabatic conditions. The temperature of the combustor for the base case run was $2,236^{\circ} \mathrm{F}$ with a recycle ratio of 0.234 . Since this temperature was higher than expected, the following parametric studies were conducted to determine the cause.

Heat Capacity -- The heat capacity for the major mineral component, illite (Table 1), had the greatest effect on combustor temperature. Communication with Los Alamos and IMMR helped obtain data on muscovite which is similar in molecular structure to illite. Mobil, who did an analysis for IMMR, identified the major clay mineral in a New Albany shale as muscovite. When the heat capacity data of illite from a past study at METC was used (the base case used the physical property data of muscovite), the combustor temperature increased by $249^{\circ} \mathrm{F}$. This was expected since the heat capacity for illite is less than that of muscovite. (See Figure 3.) This was approximately a 35 percent reduction in heat capacity from the base case. Therefore, less heat is absorbed when the heat capacity of illite is used and the combustor temperature increases.

Stoichiometric Equation -- The stoichiometric equation in the retort was varied to determine its effect on combustor temperature. The base case run had a ratio of 43 percent of pounds-of-residue-formed per pound-of-kerogen-consumed. The new stoichiometric equation used for the parametric study had a ratio of 34 percent. For 1,000 $\mathrm{lbs}$ of raw shale feed (the feed stream rate used in this simulation), 90 lbs less residue was formed than in the base case. The net effect was a reduction in temperature of $202^{\circ} \mathrm{F}$ and an increase in the recycle ratio. This shows the need to accurately define the pyrolysis reactions that take place in the retort.

Percent Carbon Combusted -- As less carbon is burned, the combustor temperature decreases. Therefore, it is necessary to determine the percent of carbon that is burned. Lowering the carbon from 90 percent (base case) to 70 percent reduced the combustor temperature by $190^{\circ} \mathrm{F}$. By performing ultimate analyses on the oil shale before and after combustion, this percentage could be accurately defined.

Heat of Formation of Raw 0il -- This parameter was very interesting because, although increasing the heat of formation had the smallest effect on the combustor temperature (a $116^{\circ} \mathrm{F}$ reduction), it had the greatest effect on the recycle ratio. (See Table 4.) By increasing the heat of formation of the oil, more heat was required in the retort because more heat was needed to pyrolyze the shale.

All Parameters Varied -- All the parameters in the sensitivity study were varied (except the heat capacity of illite for which the heat capacity of muscovite was used) to determine the result this would have on reducing the abnormally high combustor temperature. The total effect was a reduction in the combustor temperature from $2,236^{\circ} \mathrm{F}$ to $1,749^{\circ} \mathrm{F}$, and an increase in the recycle ratio from 0.246 to 0.71 . This shows that wide variation in the base case simulation results can be caused by changing only a few parameters. Therefore, the importance of obtaining data to accurately define input parameters must be stressed. 


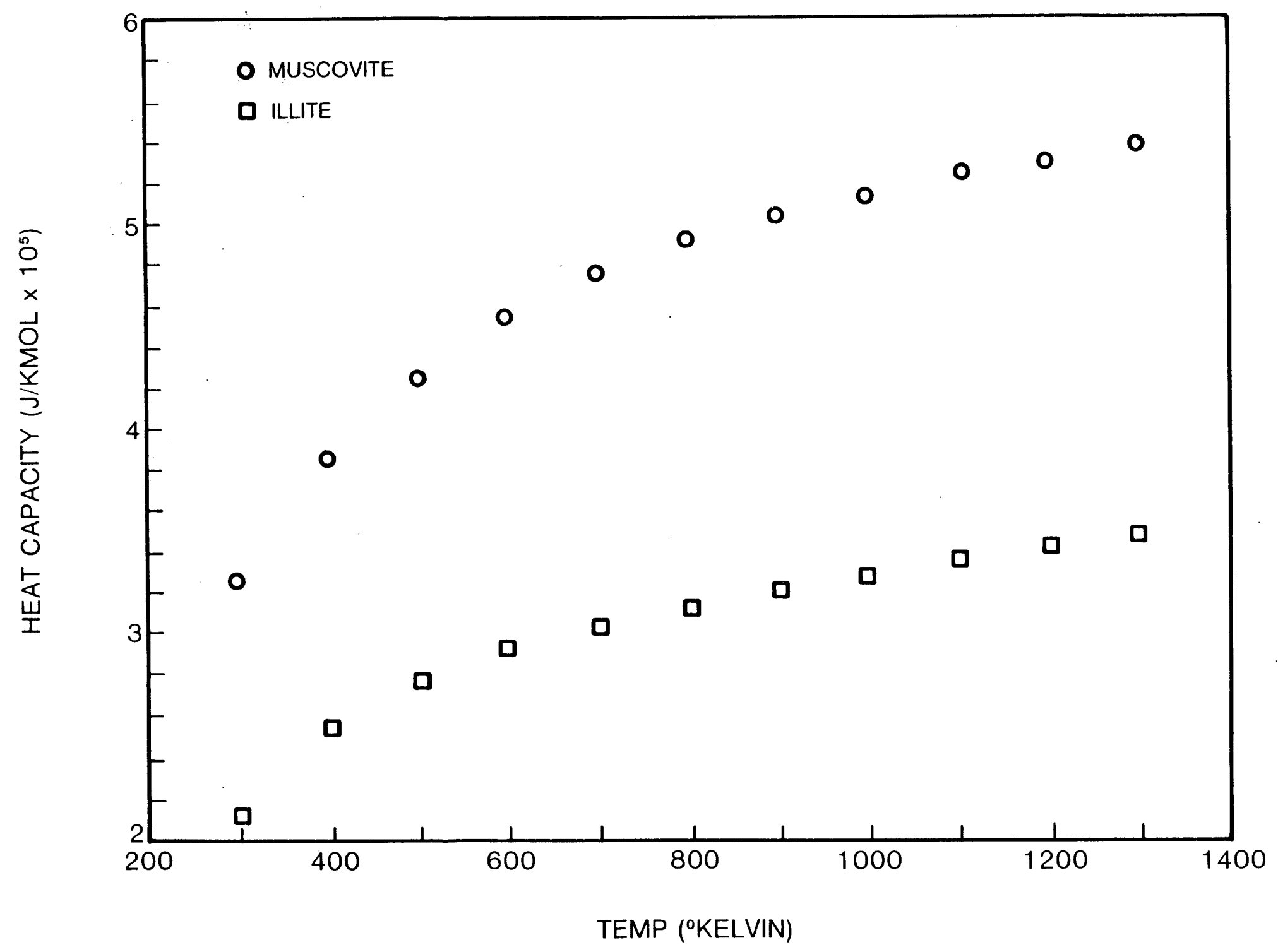

FIGURE 3. COMPARISON OF THE HEAT CAPACITY OF MUSCOVITE AND ILLITE 


\subsection{CONCLUSIONS AND RECOMMENDATIONS}

The effort to develop a model of a fluidized-bed retort/combustion process showed that accurate data are very important. By varying assumptions made on some input variables, the process variables differed significantly, showing that for any set of assumptions, different results could be obtained. However, the results of this type of simulation would not be significant because too many assumptions were made. Therefore, it is necessary to stress the importance of obtaining accurate data to reduce the number of assumptions in order to increase the level of confidence in the simulation results. By implementing the recommendations in Sections 3.2 and 3.3 , a more realistic and accurate model of a fluidized-bed retort/combustion process for an eastern oil shale will be developed. 


\subsection{REFERENCES}

Ahmed, M.M., D.W. Parker, and D.H. Archer. 1983. Processing of Eastern Oil Shales for Fuel Recovery. In 1982 Eastern Oil Shale Symposium Proceedings. pp. 163-168. Lexington: University of Kentucky Institute for Mining and Minerals Research.

Battelle, Columbus Laboratories. 1984. Development of the Multi-Solid Fluidized-Bed Oil Shale Retort. Final Report to DOE. DOE/FE/60195-1720. NTIS/DE85003355.

Braun, R.I. 1981. Mathematical Modeling of Modified In Situ and Aboveground Oil Shale Retorting. Lawrence Livermore National Labs, UCRL-53119.

Burnham, A.K., and R.L. Braun. 1984. General Model of Oil Shale Pyrolysis, Lawrence Livermore National Labs Preprint, UCRL-89805, Revision I.

Carly, J.F. 1975. Heat of Kerogen Decomposition and Improved EnthalpyTemperature Relationships for Raw and Spent Colorado Oil Shales. Earth Science Division of Lawrence Livermore National Labs. Photocopy.

Carter, S.D., and D.N. Taulbee. 1985. Fluidized-Bed Retorting of Eastern U.S. Oil Shale. In 1984 Eastern Oil Shale Symposium Proceedings. pp. 267-279. Lexington: University of Kentucky Institute for Mining and Minerals Research.

Diaz, J.C., and R.L. Braun. 1984. Process Simulation Model for a Staged, Fluidized-Bed Oil Shale Retort with Lift-Pipe Combustor. Lawrence Livermore National Labs, UCRL-53517.

Fong, L., J.K. Floess, C.C. Chen, J.P. Longwell, and L.B. Evans. 1981. Modeling of an Oil Shale Fluidized-Bed Retorting Process using ASPEN. Paper presented at $\mathrm{AIChE} 91$ st National Meeting.

Jones, II, W., D. Lyzinki, J.B. Miller, A.V. Cugini, and F.J. Antezana. 1984. Gulf Shale Oil Upgrading Process Technology. In 1983 Seventeenth Oil Shale Symposium Proceedings. Colorado School of Mines.

National Bureau of Standards. 1971. JANAF Thermochemical Tables, 2nd ed. Washington, DC: U.S. Department of Commerce.

Phillips, T.T., K.A. Odell, W.J. Parkinson, R.C. Rex, and J.C. Janka. 1985. ASPEN Simulation of Commercial Hytort Reactor Configurations. In 1984 Eastern Oil. Shale Symposium Proceedings. pp. 321-330. Lexington: University of Kentucky Institute for Mining and Minerals Research.

Robie, R.A. 1978. Thermodynamic Properties of Minerals and Related Substances at $298.15 \mathrm{~K}$ and 1 Bar (10E Pascals) Pressure and at Higher Temperatures. Washington, $\overline{D C}$ : Government Printing Office. 


\section{APPENDIX A: ASPEN INPUT FILE FOR THE BASE CASE}

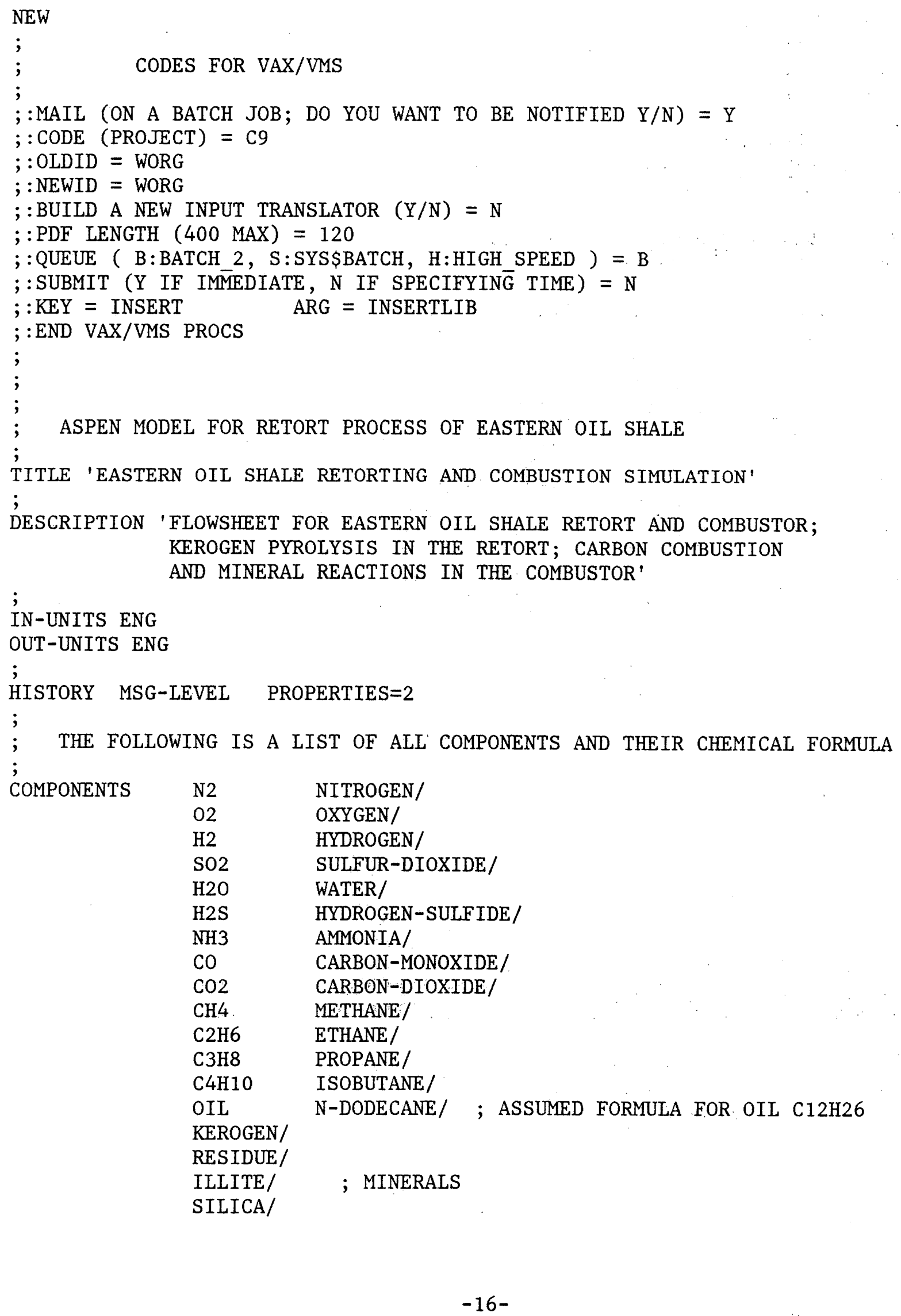




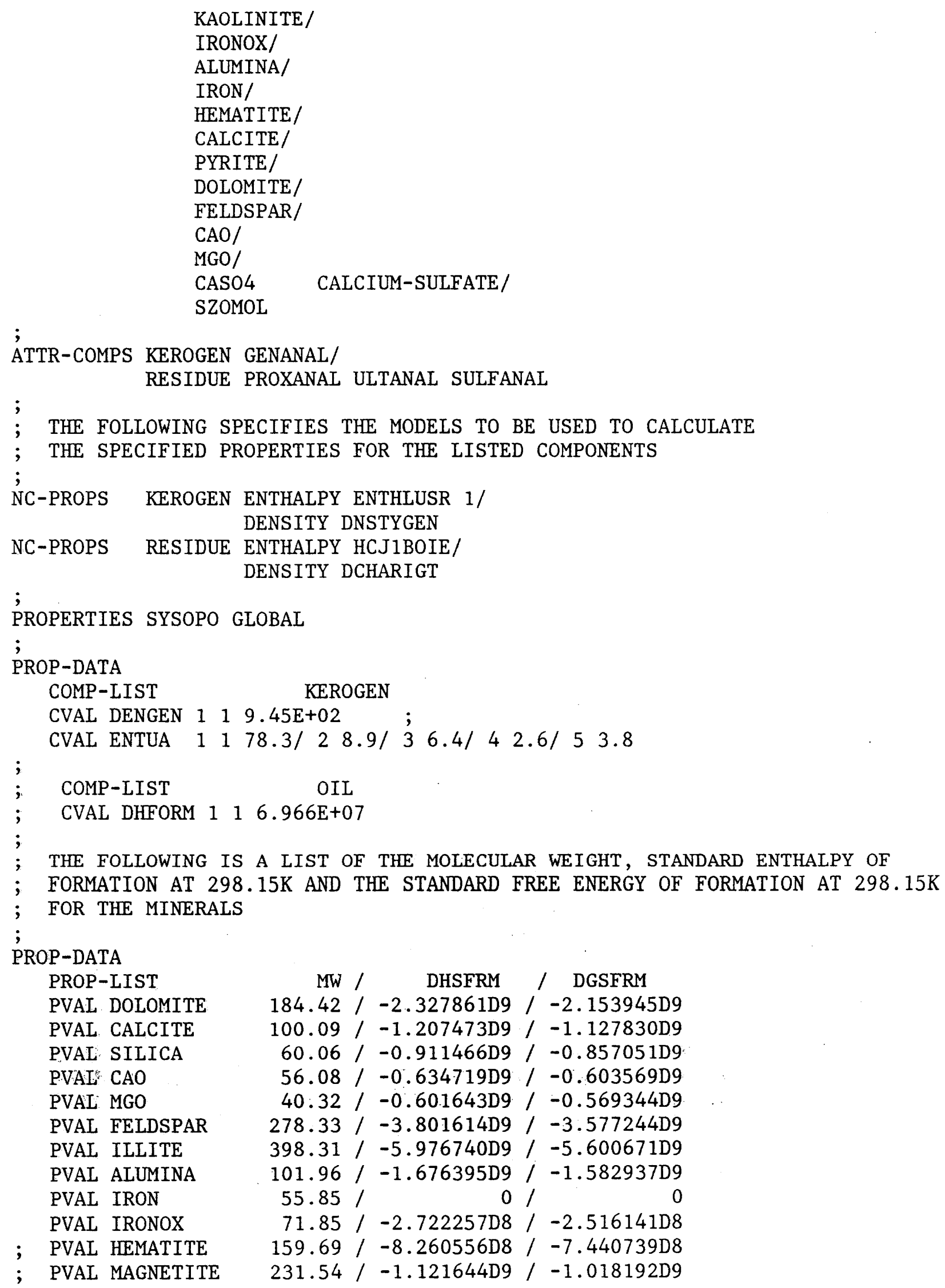


$\begin{array}{lrllll}\text { PVAL PYRITE } & 119.98 /-1.782000 D 8 /-1.669000 D 9 & \\ \text { PVAL KAOLINITE } & 258.16 /-4.119600 D 9 /-3.799700 D 9 & \\ \text { PVAL MAGNESITE } & 84.32 /-1.105000 D 9 /-1.029000 D 9 & \\ \text { PVAL SZOMOL } & 170.00 /-8.000000 D 8 /-1.500000 D 9\end{array}$

; THE FOLLOWING IS A LIST OF THE PURE SOLID HEAT CAPACITY

; PARAMETERS AND THE TEMPERATURE RANGE FOR THE MINERALS 


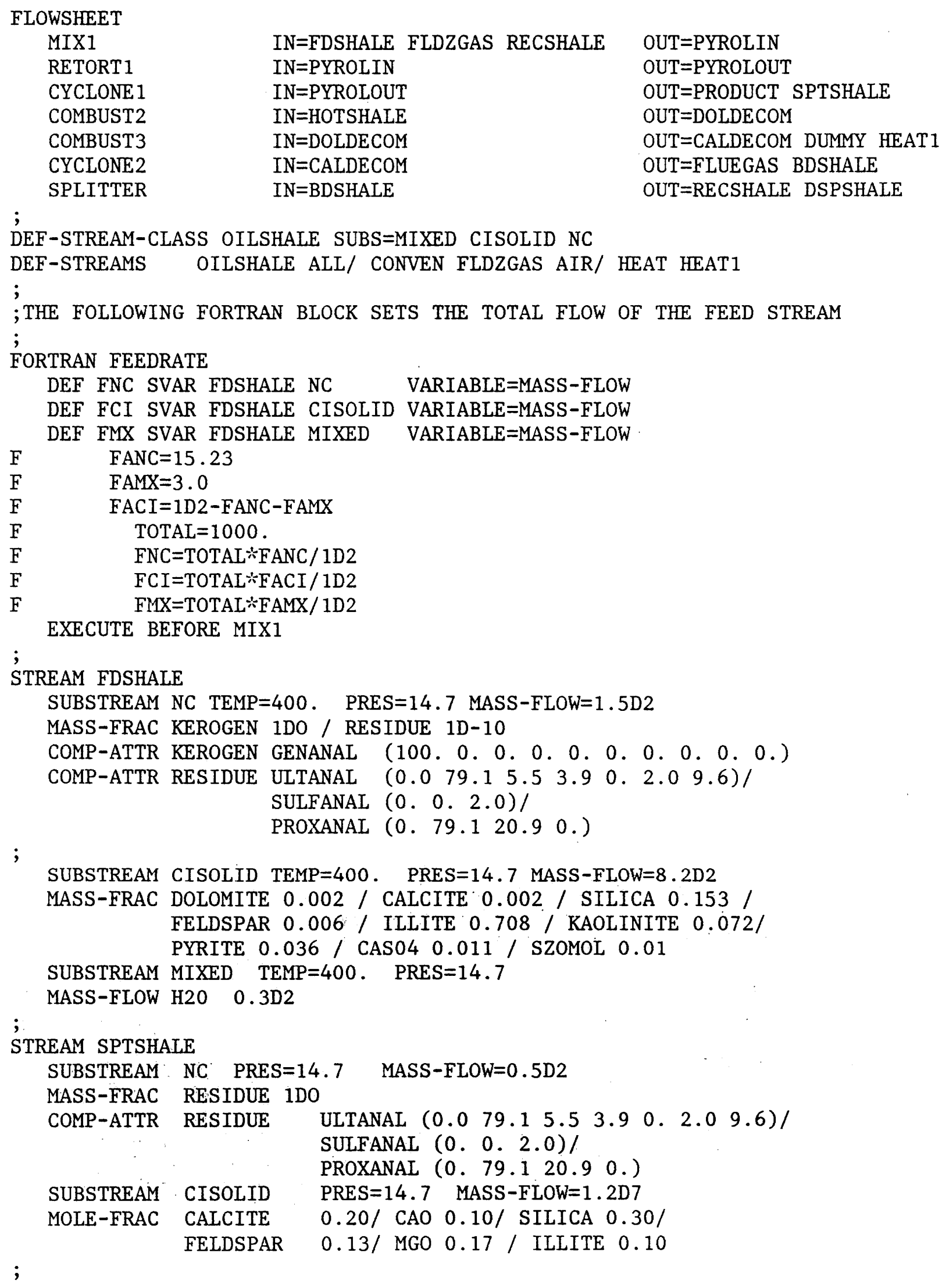




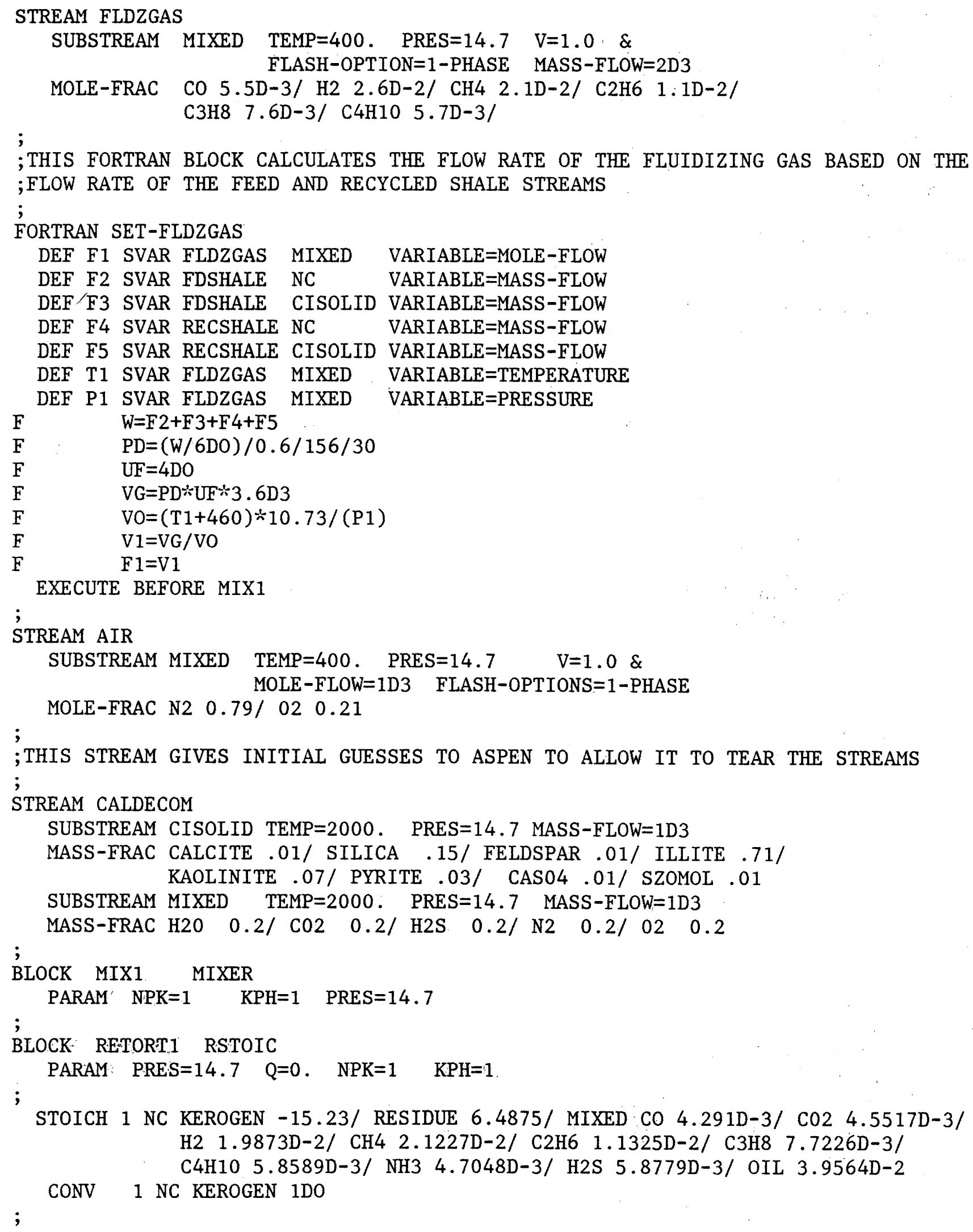




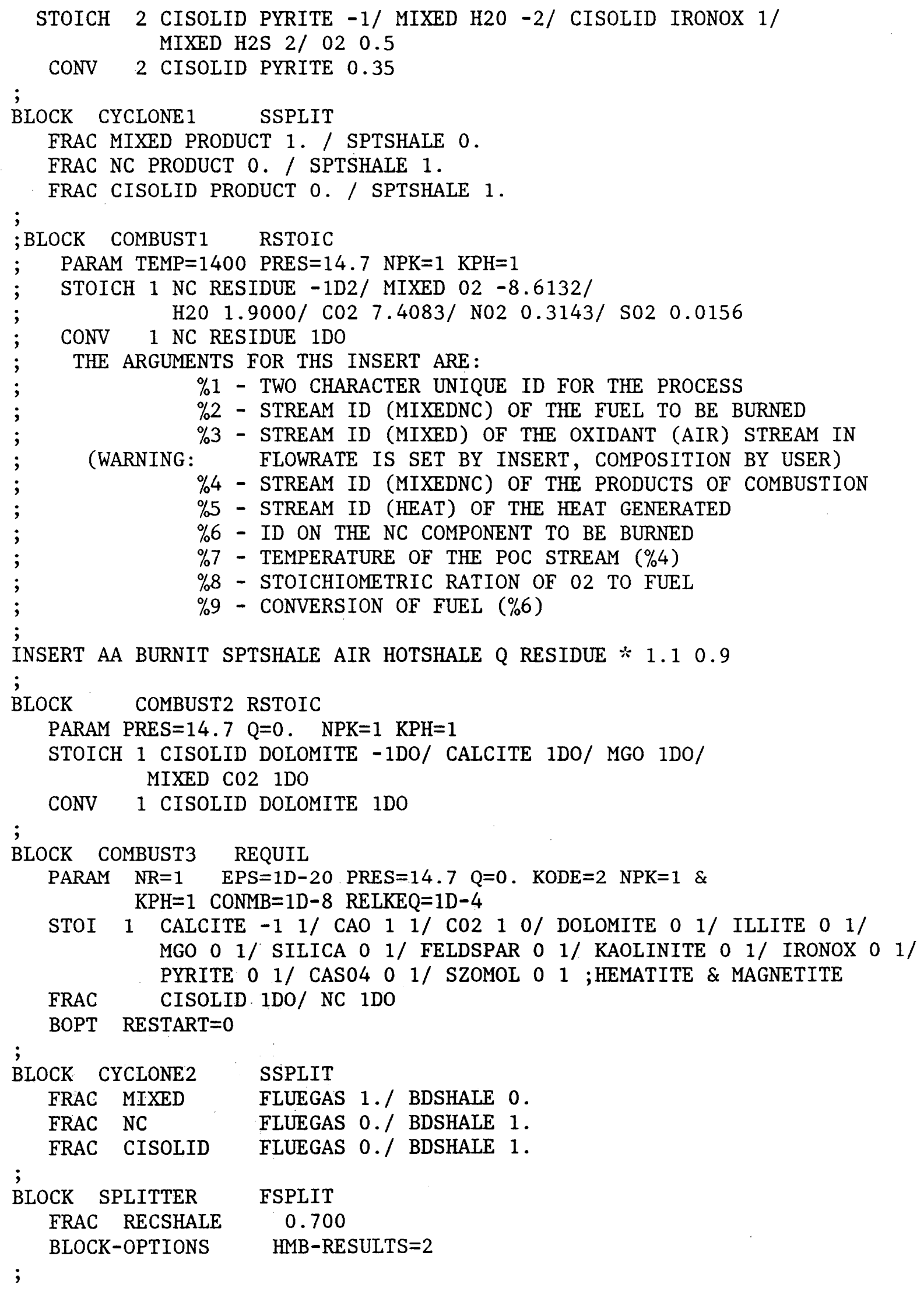




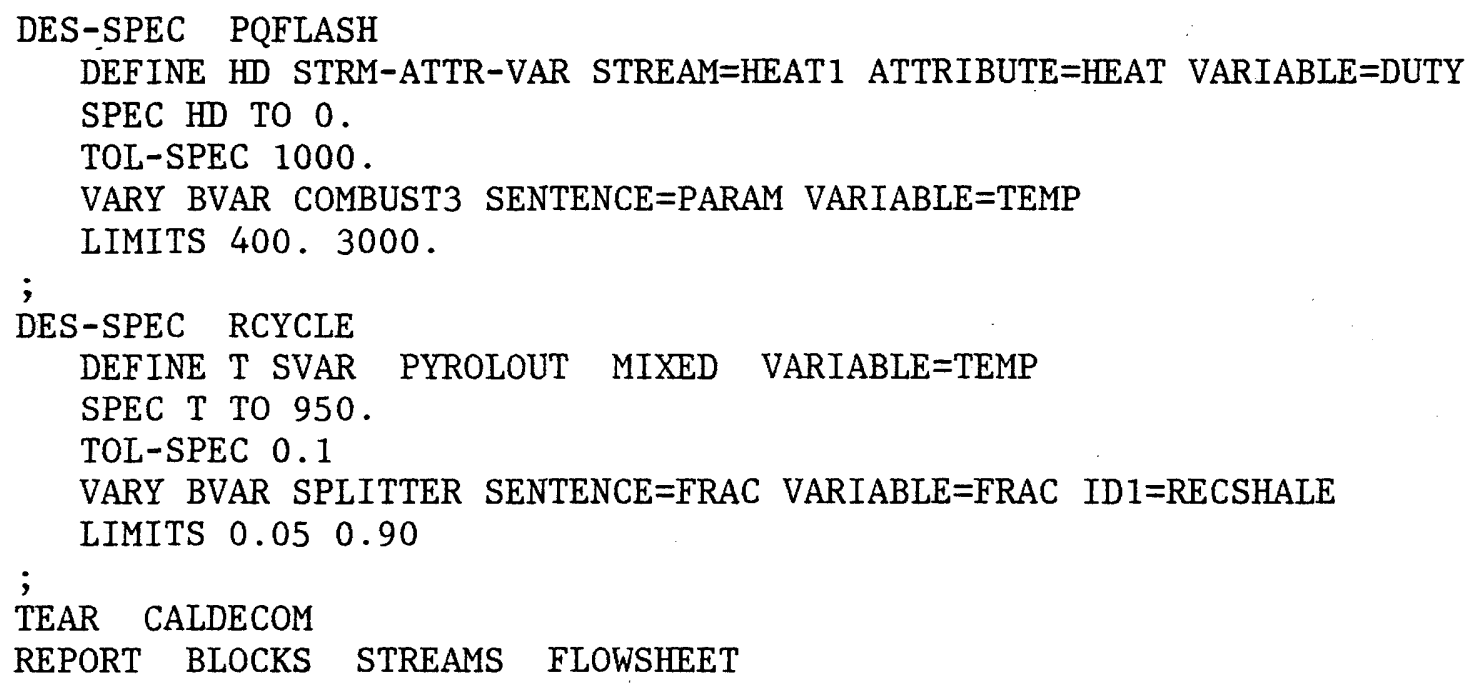




\section{APPENDIX B: CALCULATIONS FOR STOICHIOMETRY OF NEW ALBANY SHALE}

Composition of New Albany Shale:

Product 0il from the Retort:

\begin{tabular}{lr} 
Analysis & Wt $\%$ \\
\hline Carbon (organic) & 11.93 \\
Hydrogen (organic) & 1.36 \\
Oxygen (organic)* & .97 \\
Nitrogen (organic)* & .39 \\
Sulfur (organic)* & .58 \\
Minerals & 81.77 \\
Moisture & 3.00 \\
& 100.00
\end{tabular}

\begin{tabular}{lr} 
Analysis & \multicolumn{1}{c}{ Wt $\%$} \\
\hline Carbon & 83.2 \\
Hydrogen & 9.8 \\
Oxygen & 2.0 \\
Nitrogen & 1.1 \\
Sulfur & 3.9 \\
& 100.0
\end{tabular}

From studies on fluidized-bed retorting:

- 45 to 47 percent raw carbon $\rightarrow$ oil (this study assumes 47 percent).

- 5 to 10 percent raw carbon $\rightarrow$ gas (this study assumes 10 percent).

- Remaining 43 percent raw carbon $\rightarrow$ residue.

For each 100 lbs of raw shale feed:

Carbon in oil $=\quad .47 \times 11.93=5.61 \mathrm{lbs}$.

Carbon in gas $=.10 \times 11.93=1.19 \mathrm{lbs}$.

Carbon in residue $=.43 \times 11.93=5.13 \mathrm{lbs}$.

Using the product oil analysis, if carbon is 83.2 percent by weight, then

Total wt. of oil $=5.61 \mathrm{lbs}$ carbon $/ .832=6.74 \mathrm{lbs}$ oil

Using the product oil analysis, the pounds of $\mathrm{C}, \mathrm{H}, \mathrm{O}, \mathrm{N}$, and $\mathrm{S}$ can be obtained for the oil.

A gas composition was assumed as follows:

Compound $\quad \underline{W t} \%$

$\begin{array}{lr}\mathrm{CH}_{4} & 17.0 \\ \mathrm{C}_{2} \mathrm{H}_{6} & 17.0 \\ \mathrm{C}_{3} \mathrm{H}_{8} & 17.0 \\ \mathrm{C}_{4} \mathrm{H}_{10} & 17.0 \\ \mathrm{H}_{2} & 2.0 \\ \mathrm{NH}_{3} & 4.0 \\ \mathrm{H}_{2} \mathrm{~S} & 10.0 \\ \mathrm{CO} & 6.0 \\ \mathrm{CO}_{2} & 10.0 \\ & 100.0\end{array}$

*The percentage of oxygen, nitrogen, and sulfur that is organic is assumed. 
The weight percentages of $\mathrm{C}, \mathrm{H}, \mathrm{O}, \mathrm{N}$, and $\mathrm{S}$ were obtained by using the molecular weights of each component. The total pounds of gas were calculated by:

Total weight of gas $=1.19 / .596$ ( $w t \%$ of carbon $)=2.001 \mathrm{bs}$

The pounds of $\mathrm{C}, \mathrm{H}, \mathrm{O}, \mathrm{N}$, and $\mathrm{S}$ were then calculated by using the total pounds of gas and the weight percentages of $\mathrm{C}, \mathrm{H}, \mathrm{O}, \mathrm{N}$, and $\mathrm{S}$ in the gas.

The composition of the residue or spent shale was calculated by taking the pounds of $\mathrm{C}, \mathrm{H}, \mathrm{O}, \mathrm{N}$, and $\mathrm{S}$ in the oil and gas and subtracting this from the Kerogen analysis.

Organic

Residue (Spent

Shale) Analysis $\quad$ Wt $\%$

Carbon

79.1

Hydrogen

Oxygen

5.5

Nitrogen

9.6

Sulfur

3.9

$\frac{2.0}{100.0}$ 
TABLE 5. STOICHIOMETRIC TABLE

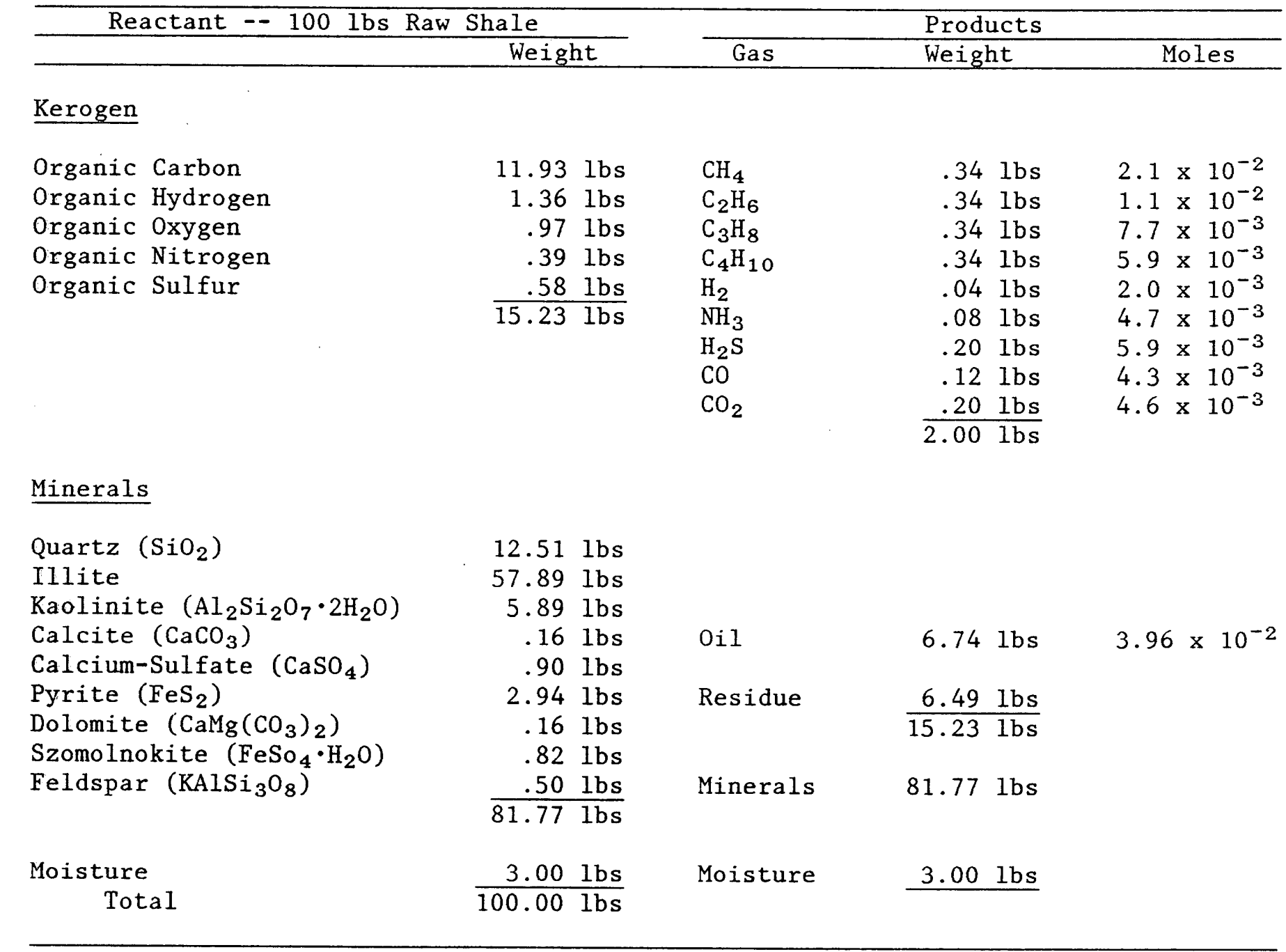


Identification of Data Gaps Found During the Development of a Zero-Order Model for Fluidized-Bed Retort/Combustion Process 